\section{Transmission potential of Colletotrichum lindemuthianum (race 65) in association with bean seeds under controlled conditions}

\author{
Stélio Jorge Castro Gadaga ${ }^{1}$ (D) Carolina da Silva Siqueira ${ }^{*}{ }^{(\mathbb{D}}$, José da Cruz \\ Machado ${ }^{1}$
}

ABSTRACT: Anthracnose, caused by Colletotrichum lindemuthianum, is one of the main diseases affecting common bean in Brazil, and field losses can reach $100 \%$. Transmission of this pathogen from seeds to seedlings/plants may vary according to environmental conditions and initial inoculum levels, among other factors. The aim of this study was to quantify the transmission rate of $C$. lindemuthianum, race 65 , from infected bean seeds to seedlings/plants under controlled conditions. Seed inoculation was performed by the water conditioning technique in order to obtain seeds with different inoculum potentials as a result of the exposure time of the seeds to the fungus in pure culture, with the potentials denominated P0, P36, P72, P108, and P144. Inoculated and non-inoculated seeds were individually sown and kept in growth chambers under two temperatures, 20 and $26{ }^{\circ} \mathrm{C}$, for a period of 28 days. There was transmission of the pathogen in both asymptomatic and symptomatic plants. The highest total transmission rate (92\%) occurred in plants originating from seeds exposed for 144 hours to the fungus at $20^{\circ} \mathrm{C}$.

Index terms: transmission, common bean anthracnose, inoculum potential.

\section{Transmissão potencial de Colletotrichum lindemuthianum (raça 65) em associação com sementes de feijão sob condições controladas}

RESUMO: A antracnose do feijoeiro, causada por Colletotrichum lindemuthianum, é uma das principais doenças que ocorre no feijoeiro e as perdas podem chegar a $100 \%$. A transmissão deste patógeno de sementes para plântulas/plantas pode variar de acordo com as condições ambientais e nível de inóculo, dentre outros fatores. O objetivo deste trabalho foi quantificar a taxa de transmissão de $C$. lindemuthianum, raça 65, a partir de sementes de feijão infectadas. A inoculação das sementes foi realizada pela técnica de condicionamento hídrico com o intuito de se obter sementes com diferentes potenciais de inóculo, em função do tempo de exposição das sementes com o fungo em cultura pura, sendo os potenciais denominados: P0, P36, P72, P108 e P144. Sementes não inoculadas e inoculadas foram semeadas individualmente e mantidas em câmaras de crescimento vegetal sob duas temperaturas de crescimento, 20 e $26^{\circ} \mathrm{C}$ pelo período de 28 dias. Observou-se que, tanto em plantas assintomáticas, quanto nas sintomáticas, houve transmissão do patógeno. $\mathrm{A}$ maior taxa de transmissão total (92\%) ocorreu nas plantas originadas a partir de sementes expostas por 144 horas ao fungo e a $20^{\circ} \mathrm{C}$.

Termos para indexação: transmissão, antracnose do feijoeiro, potencial de inóculo.
Journal of Seed Science, v.42, e202042025, 2020

http://dx.doi.org/10.1590/ 2317-1545v42231421

\footnotetext{
*Corresponding author E-mail: kerolpet@gmail.com

Received: $11 / 25 / 2019$ Accepted: 5/26/2020.
}

${ }^{1}$ Departamento de Fitopatologia, Universidade Federal de Lavras UFLA, Caixa Postal 3037, 37200-000, Lavras, MG, Brasil. 


\section{INTRODUCTION}

Anthracnose caused by Colletotrichum lindemuthianum (Sacc. \& Magn.) Briosi \& Cav. is one of the most serious diseases of common bean in Brazil. The fungus is transmitted by seeds, which are responsible for introduction and significant concentrations of the inoculum in growing areas. Seeds are an effective vehicle for dissemination of this organism (Maringoni and Barros, 2002; Sartori et al., 2004; Vechiato et al., 1997; Vieira, 1988; Ferreira et al., 2019).

This understanding indicates that one of the main strategies for control of anthracnose is the use of pathogen-free seeds, preventing its dissemination to healthy plants of a given population and to other growing regions (Sartori et al., 2004; Vieira, 1988).

Transmission of $C$. lindemuthianum from seeds to seedlings is known to occur quickly and effectively. In Rey et al. (2009), common bean seeds of the cultivar Líder, belonging to the white bean class, were exposed to $C$. lindemuthianum (races 65, 73, and 81) for 96 hours. Even though the seeds had not been coated across $100 \%$ of their area, they showed high transmission rates of the fungus, which ranged from 70 to $80 \%$. In addition, symptoms typical of the fungus were observed in all parts of the plants, the cotyledons, stems, and leaves.

The presence of the pathogen in seeds constitutes the primary inoculum source, and it may lead to damage in seed performance in a variable manner. The pathogen may affect establishment of the crop and cause reductions in the plant population, reducing its yield. Furthermore, it remains in the crop area, constituting a source of the inoculum for subsequent crops (Talamini et al., 2001).

Studies on $C$. lindemuthianum transmission in common bean seeds have not taken into account the presence of the pathogen in tissues of asymptomatic emerged plants or in dead seeds or seedlings in pre-emergence. These evaluations, as a complement to recognition of the presence of the pathogen in symptomatic plants, are of extreme importance, particularly from the epidemiological perspective. It is also important to emphasize that the probability of transmission of the fungus increases with colonization of the internal seed tissues, particularly in the embryo (Agarwal and Sinclair, 1987; Neergaard, 1979).

Given this scenario, the aim of this study was to evaluate the transmissibility of $C$. lindemuthianum (race 65 ) from common bean seeds to plants based on different levels of inoculum potential and on environmental growing conditions.

\section{MATERIALS AND METHODS}

Origin, multiplication of Colletotrichum lindemuthianum (race 65), and seed profile

For this study, the isolate of $C$. lindemuthianum (LV238), race 65, was used, granted by the Plant Resistance Laboratory of the Department of Biology of the Universidade Federal de Lavras. This isolate was cultivated in M3 medium [ $10 \mathrm{~g}$ of sucrose, $20 \mathrm{~g}$ of agar, $2 \mathrm{~g}$ of $\mathrm{KH}_{2}\left(\mathrm{PO}_{4}\right), 1 \mathrm{~g}$ of $\mathrm{MgSO}_{4} 7 \mathrm{H}_{2} \mathrm{O}, 6 \mathrm{~g}$ of neopeptone/peptone, $4 \mathrm{~mL}$ of panvit, and $1 \mathrm{~mL}$ of chloramphenicol per liter of distilled water] in 15-cm Petri dishes and kept in a BOD chamber at $20 \pm 2{ }^{\circ} \mathrm{C}$ and twelve-hour photoperiod for seven days. The Pérola cultivar of the Carioca common bean group, susceptible to C. lindemuthianum, was used, with initial germination percentage of 95.5\%, evaluated according to the Rules for Seed Testing (Brasil, 2009a), and incidence of $0.5 \%$ of seeds with Aspergillus flavus and $0.5 \%$ with Penicillium sp. detected through the seed health test (Brasil, 2009b).

A randomized block design was used to conduct the experiments, using four replications per treatment, and two cultivation temperatures.

Obtaining seeds infected by Colletotrichum lindemuthianum with different inoculum potentials

To obtain 'Pérola' common bean seeds with different levels of pathogen inoculum potential, the water conditioning method was followed (Botelho et al., 2013; Machado et al., 2012). The seeds were initially desinfested with $1 \%$ sodium hypochlorite for 1 minute and then washed three times in distilled water, with subsequent drying on two sheets of 
Germitest (germination testing paper) in plastic trays in a laboratory environment for 48 hours. Fungal colonies at seven days of age were obtained in Petri dishes containing M3 medium with the addition of mannitol, with potential adjusted to -1.0 MPa (Michel and Radcliffe, 1995). Seeds were distributed in a single layer on this agarized medium in a uniform manner. The Petri dishes with seeds were kept in a BOD chamber at $20 \pm 2{ }^{\circ} \mathrm{C}$ and twelve-hour photoperiod for periods of $0,36,72,108$, and 144 hours, which corresponded to the different inoculum potentials denominated P0, P36, P72, P108, and P144, respectively. After each period of contact between fungi and seeds, the seeds were transferred from the Petri dishes to plastic trays containing two sheets of Germitest paper, remaining at ambient temperature for 48 hours.

\section{Sowing under controlled conditions and evaluations}

A randomized block experimental design was used to carry out the experiments, with four replications per treatment and two growing temperatures.

For each treatment, 100 inoculated seeds were sown individually in $200 \mathrm{~mL}$ plastic cups containing a mixture of Plantmax ${ }^{\circledR}$ commercial substrate, soil and sand at a 1:1:1 proportion. The cups were placed in four plastic trays, 25 cups in each tray, obtaining four replications. The experiment was conducted in two plant growth chambers with temperatures adjusted to $20 \pm 2{ }^{\circ} \mathrm{C}$ and $26 \pm 2{ }^{\circ} \mathrm{C}$, and twelve-hour photoperiod. The plants were kept under these conditions for 28 days after sowing (D.A.S.). Symptomatic and asymptomatic plants were counted daily.

Fragments $(2 \mathrm{~cm})$ from symptomatic and asymptomatic plants, removed at the height of the root collar (C) and of the top leaf node (LN), were placed in Petri dishes containing M3 medium at the temperature of $20{ }^{\circ} \mathrm{C}$ and 12 -hour photoperiod for seven days for confirmation of the presence of $C$. lindemuthianum in their tissues. The fragments were first desinfested for one minute in each one of the following products: $70 \%$ alcohol, $1 \%$ sodium hypochlorite, and distilled and sterilized water. They were then dried on sterilized paper at ambient temperature. After this period, the fragments were individually evaluated in a stereoscopic microscope for observation of the characteristic structures of C. lindemuthianum.

Confirmation of fungus transmission from seeds to plants was assumed when at least one of the fragments (C or LN) indicated the presence of $C$. lindemuthianum. The total transmission rate was calculated considering the symptomatic plants, asymptomatic plants (occurrence of the fungus in parts of the asymptomatic plants), and dead seedlings in preemergence (Siqueira et al., 2014).

The experiment was conducted in a randomized block design with one cultivar, two temperatures, and four inoculum potentials, with four replications per treatment.

\section{Statistical analysis}

Statistical analysis was carried out using the Sisvar ${ }^{\circledR} 5.6$ program (Ferreira, 2011). When the variable was significant in the $\mathrm{F}$ test, the mean values among the treatments were compared by the regression test at $5 \%$ probability.

\section{RESULTS AND DISCUSSION}

Analyses of variance for the variables - death of seeds.seedlings ${ }^{-1}$ in pre-emergence, transmission rates in symptomatic and asymptomatic plants, and total transmission rate from seeds to emerged plants when the seeds were inoculated with C. lindemuthianum (race 65) - revealed non-significant differences ( $\leq 0.05$ ) among the treatments (Tables 1 and 2).

According to the control treatments, there was no interference from the water restrictor mannitol on seed performance.

The results observed in this study show that the fungus $C$. lindemuthianum did not cause a significant effect on seed death in pre-emergence and common bean seedlings. However, their effects can be observed afterwards through the appearance of anthracnose symptoms on emerged plants on the cotyledons, stems, and leaves, which constitute sources of inoculum that can disseminate the pathogen in the current crop and in the following crops.

There was an increase in seedling death in pre-emergence related to inoculum potential with the temperature of $20^{\circ} \mathrm{C}$, which is a factor that favors development of anthracnose (Figure 1). Death in pre-emergence of seeds and 
Table 1. Transmission rates of Colletotrichum lindemuthianum, race 65, isolate LV238, to plants from inoculated seeds with different seed-fungus contact periods, corresponding to the inoculum potentials P0 (0 h), P36 (36 h), P72 (72 h), P108 (108 h), and P144 (144 h).

\begin{tabular}{|c|c|c|c|c|}
\hline \multicolumn{5}{|c|}{ Tests in a plant growth chamber* } \\
\hline Treatments & $\begin{array}{c}\text { Death in } \\
\text { pre-emergence (\%) }\end{array}$ & $\begin{array}{l}\text { Transmission rate in } \\
\text { symptomatic plants (\%) }\end{array}$ & $\begin{array}{l}\text { Transmission rate in } \\
\text { asymptomatic plants (\%) }\end{array}$ & $\begin{array}{c}\text { Total transmission rate } \\
(\%)\end{array}$ \\
\hline $\mathrm{PO}-20^{\circ} \mathrm{C}$ & 5 & 0 & 0 & 5 \\
\hline $\mathrm{P} 36-20^{\circ} \mathrm{C}$ & 15 & 6 & 11 & 32 \\
\hline $\mathrm{P} 72-20^{\circ} \mathrm{C}$ & 24 & 9 & 14 & 47 \\
\hline $\mathrm{P} 108-20^{\circ} \mathrm{C}$ & 30 & 25 & 20 & 75 \\
\hline P144 - $20^{\circ} \mathrm{C}$ & 35 & 29 & 28 & 92 \\
\hline $\mathrm{PO}-26^{\circ} \mathrm{C}$ & 3 & 0 & 0 & 3 \\
\hline P36 - $26^{\circ} \mathrm{C}$ & 8 & 5 & 1 & 14 \\
\hline $\mathrm{P} 72-26^{\circ} \mathrm{C}$ & 11 & 8 & 5 & 24 \\
\hline $\mathrm{P} 108-26^{\circ} \mathrm{C}$ & 15 & 10 & 7 & 32 \\
\hline P144 - $26^{\circ} \mathrm{C}$ & 19 & 26 & 11 & 56 \\
\hline CV (\%) & 40.60 & 33.41 & 23.81 & 35.55 \\
\hline
\end{tabular}

*Significant at $0.05 \%$

Table 2. Incidence of Colletotrichum lindemuthianum, race 65, isolate LV238, in two regions analyzed of asymptomatic plants grown from inoculated seeds with different seed-fungus contact periods, corresponding to the inoculum potentials P0 (0 h), P36 (36 h), P72 (72 h), P108 (108 h), and P144 (144 h).

\begin{tabular}{ccc}
\hline & Asymptomatic plants** & \\
\hline Treatments & Incidence in C* $(\%)$ & Incidence in LN* $(\%)$ \\
\hline P0 $-20{ }^{\circ} \mathrm{C}$ & 0 & 0 \\
P36 $-20^{\circ} \mathrm{C}$ & 25 & 0 \\
P72 $-20^{\circ} \mathrm{C}$ & 75 & 0 \\
P108 $-20^{\circ} \mathrm{C}$ & 75 & 0 \\
P144 $-20^{\circ} \mathrm{C}$ & 74 & 25 \\
P0 $-26^{\circ} \mathrm{C}$ & 0 & 0 \\
$\mathrm{P} 36-26^{\circ} \mathrm{C}$ & 81 & 19 \\
$\mathrm{P} 72-26^{\circ} \mathrm{C}$ & 83 & 52 \\
$\mathrm{P} 108-26^{\circ} \mathrm{C}$ & 89 & 36 \\
$\mathrm{P} 144-26^{\circ} \mathrm{C}$ & 97 & 54 \\
\hline $\mathrm{CV}(\%)$ & 36.57 & 47.88
\end{tabular}

${ }^{*} \mathrm{C}$ - root collar of asymptomatic plant; LN - top leaf node of asymptomatic plant.

**Significant at $0.05 \%$.

seedlings ranged from 16 to $30 \%$. Some pathogens in other pathosystems proved to be more damaging to seeds in pre-emergence, such as Stenocarpella macrospora, which caused death in pre-emergence of maize seeds in a range from 61 to $73.5 \%$ at the higher inoculum potentials (Siqueira et al., 2014). The results of the present study show that C. lindemuthianum does not cause significant death of its host in pre-emergence, bearing in mind that this pathogen is 
not considered an organism that inhabits the soil (Hall, 1991).

In relation to the $C$. lindemuthianum transmission rate from seeds to symptomatic plants (Figure 2), the highest rates were observed in the plants grown from seeds with higher inoculum potentials, P108 and P144. Plants grown at the temperature of $20^{\circ} \mathrm{C}$ had a higher transmission rate, as observed in symptomatic plants, than plants grown at $26{ }^{\circ} \mathrm{C}$. In addition, the highest inoculum potentials led to higher fungal transmission rates, reaching $29 \%$ (P144), whereas the control (P0) did not manifest transmission.

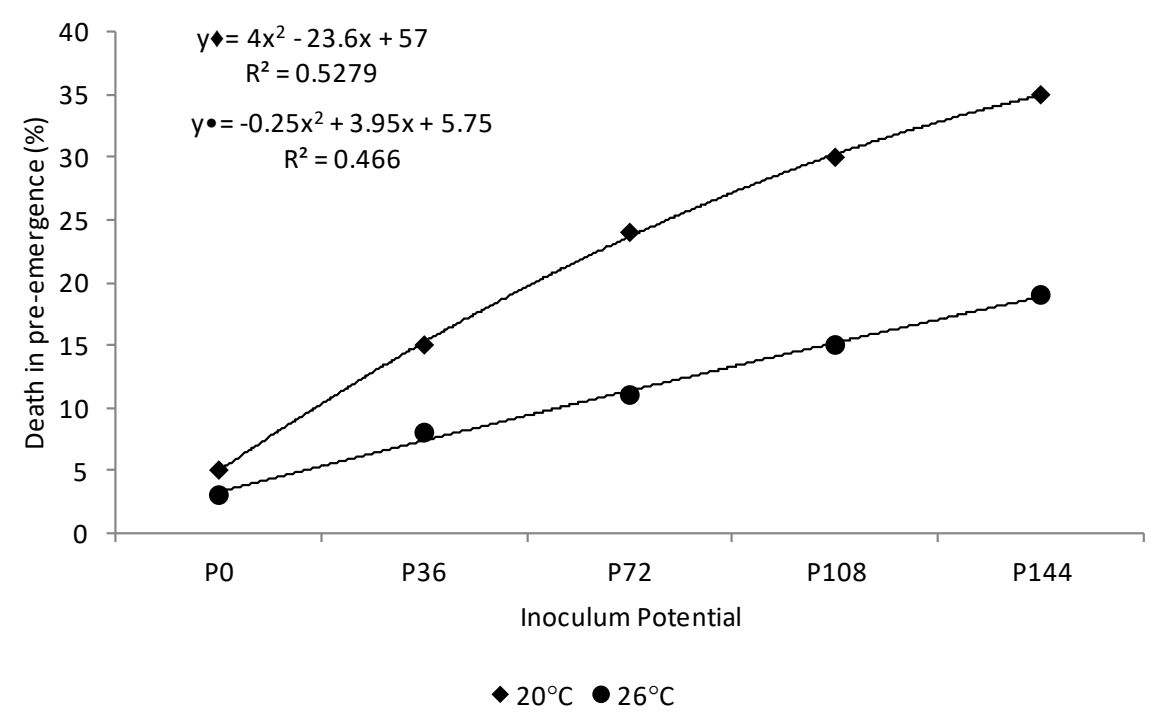

Figure 1. Percentage of death in pre-emergence of common bean ('Pérola') seeds-seedlings inoculated with the isolate LV238 of Colletotrichum lindemuthianum (race 65) with different seed-fungus contact periods $(0 \mathrm{~h}, 36 \mathrm{~h}, 72 \mathrm{~h}$, $108 \mathrm{~h}$, and $144 \mathrm{~h}$ ), corresponding to the inoculum potentials P0, P36, P72, P108, and P144, and grown at two temperatures $\left(20\right.$ and $\left.26^{\circ} \mathrm{C}\right)$.

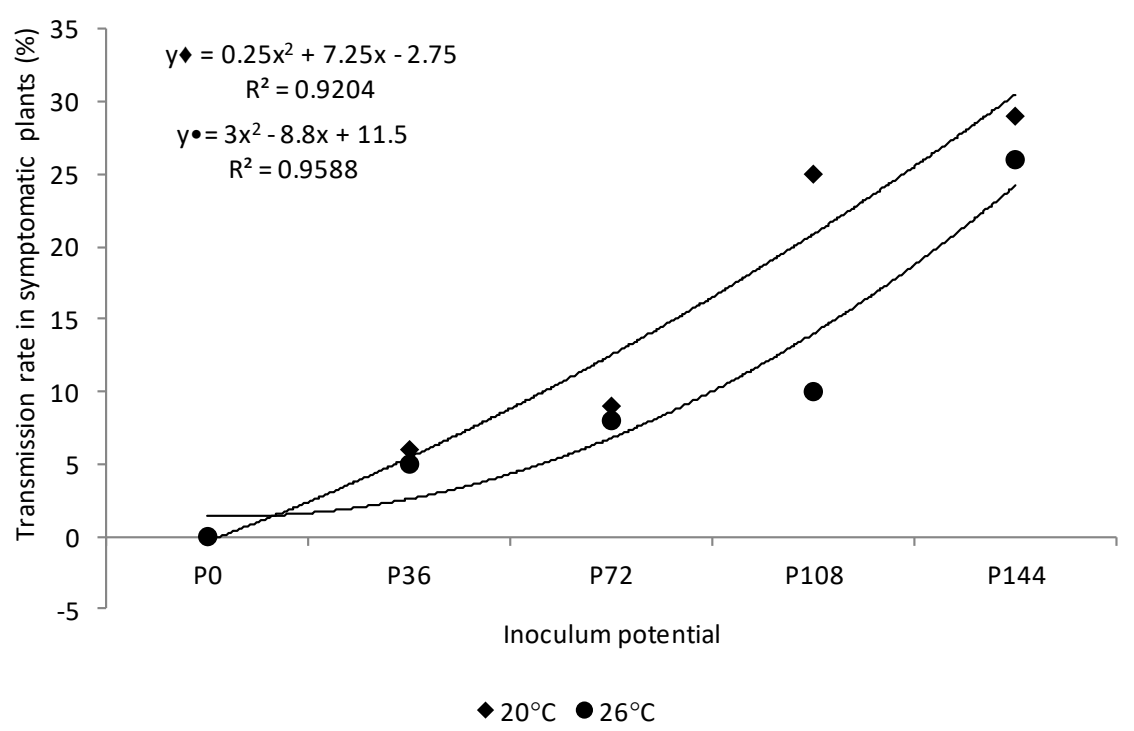

Figure 2. Transmission rate of Colletotrichum lindemuthianum (race 65), isolate LV238, in symptomatic plants of common bean ('Pérola') grown from inoculated seeds with different seed-fungus contact periods $(0 \mathrm{~h}, 36 \mathrm{~h}$, $72 \mathrm{~h}, 108 \mathrm{~h}$, and $144 \mathrm{~h}$ ), corresponding to the inoculum potentials P0, P36, P72, P108, and P144, and grown at two temperatures $\left(20\right.$ and $\left.26^{\circ} \mathrm{C}\right)$. 
From these results, it is clear that the temperature of $20^{\circ} \mathrm{C}$ is more favorable to transmission of the fungus than the temperature of $26^{\circ} \mathrm{C}$. Examples in this same line of research show different patterns of this type of transmission, although there is a tendency similar to the results of this study. In this respect, Venturoso et al. (2015) found a high rate of transmission of $S$. sclerotiorum from seeds to seedlings of some oilseed plants. In their studies on transmission of S. macrospora and S. maydis in maize, Siqueira et al. $(2014 ; 2016)$ observed that the fungal transmission rates were proportionally higher from the first inoculum potential to the last one, and there was a inverse proportionality between the inoculum potentials and the seed performance.

Therefore, a variation can be seen in the patterns of pathogen transmission in accordance with the initial inoculum potentials in the seeds. These variations among values of inoculum potential for each pathosystem lead to consideration of management strategies corresponding to each case of disease.

From examination of asymptomatic plants (Figures $3 \mathrm{~A}$ and $3 \mathrm{~B}$ ) that emerged from inoculated seeds, $C$. lindemuthianum was found to be associated with tissues of the root collar region of the plant and tissues of the top leaf node of some plants. This finding confirms the need for more careful examinations in these types of studies since asymptomatic infected tissues can ensure introduction of the fungus in the crop field or in distant fields, with disastrous consequences for the producers involved with this crop.

A noteworthy study conducted by Noetzold et al. (2014) on spatial variability of Colletotrichum truncatum in soybean showed that this pathogen is able to infect the seeds coming from infected seeds, without symptoms appearing throughout the crop cycle.

The highest pathogen transmission rate in asymptomatic plants $(28 \%)$ was observed in the plants grown at $20{ }^{\circ} \mathrm{C}$ and at the higher inoculum potentials. The lowest rate (zero) was observed in the P0 inoculum potential in plants grown at both temperatures used. When comparing only the occurrences in the plant root collar and top leaf node regions, the highest occurrences of the fungus were found in the fragments coming from the root collar region of plants that grew at the temperature of $26^{\circ} \mathrm{C}$, with a value of $97 \%$ at the P144 potential, and with a value of $74 \%$ at the $\mathrm{P} 144$ potential at $20^{\circ} \mathrm{C}$. It was also found that with the increase of the inoculum potentials, the occurrence of the fungus also increased in the fragments examined ( $C$ and $L N$ ) under the two temperature conditions, 20 and $26^{\circ} \mathrm{C}$. Siqueira et al. $(2014 ; 2016)$ report that transmission rates of the fungi S. macrospora and S. maydis in asymptomatic plants of maize were higher in the plant root collar region than in the top leaf node region. In contrast, Zancan et al. (2015) did not observe the presence of S. sclerotiorum in tissues of asymptomatic sunflower plants grown from infected seeds.

Examination of emerged plants shows that the mean transmission rate from asymptomatic plants with $C$. lindemuthianum grown at $20^{\circ} \mathrm{C}$ was in the order of $28 \%$ and at $26^{\circ} \mathrm{C}$, this value was $11 \%$.

The highest percentage of total transmission of $C$. lindemuthianum (92\%) in common bean seeds occurred at the highest inoculum potential, $\mathrm{P} 144$ at the temperature of $20^{\circ} \mathrm{C}$. At the temperature of $26^{\circ} \mathrm{C}$, the total transmission rate was $56 \%$ (Figure 4). Pathogens in other pathosystems, such as Sclerotinia sclerotiorum in common bean seeds and $S$. macrospora and S. maydis in maize seeds, led to total transmission rates at varying levels, depending on the growing temperature and inoculum potential (Siqueira et al., 2014; Siqueira et al., 2016; Zancan et al., 2015).

Given these results, it is clear that the transmission rate of pathogens through seeds of host species has variable patterns, which are affected by diverse factors. Among these factors, the initial inoculum potential in the seeds is crucial in this type of interaction.

Although the methods used in other studies to evaluate the transmission of pathogens through seeds were different, as the literature on this matter shows, the transmission rates found in other pathosystems follow a similar pattern, with specific variations for each case. As shown in this study, the temperature factor is also decisive for bringing about transmission of the pathogens in the various pathosystems. 

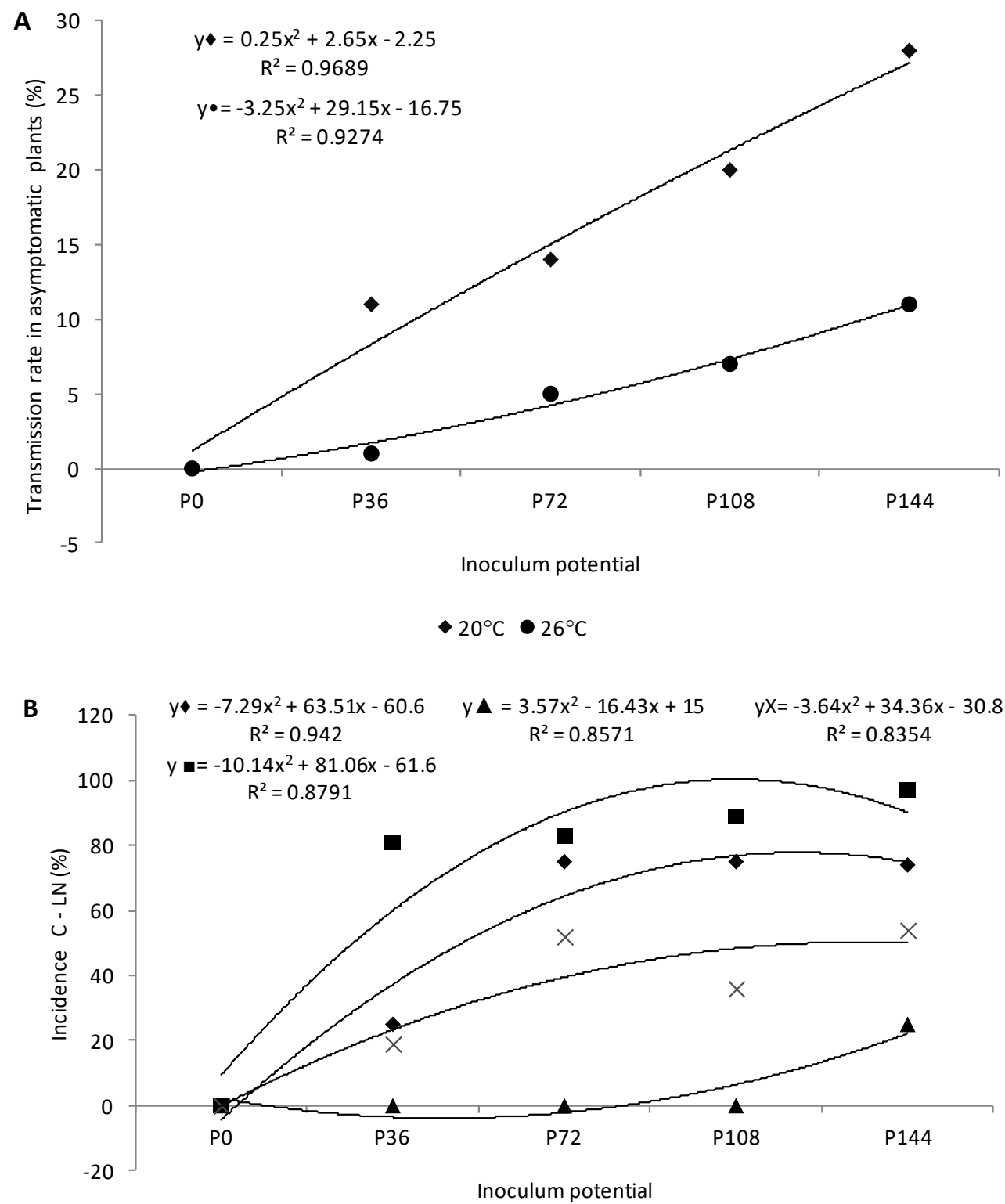

$\rightarrow 20^{\circ} \mathrm{C}-\mathrm{C} \quad \square 26^{\circ} \mathrm{C}-\mathrm{C} \quad \Delta 20^{\circ} \mathrm{C}-\mathrm{LF} \quad \times 26^{\circ} \mathrm{C}-\mathrm{LF}$

Figure 3. Transmission rate (A) and incidence of Colletotrichum lindemuthianum (B) (race 65), isolate LV238, in the region of the root collar (C) and top leaf node (LN) in asymptomatic plants of common bean ('Pérola') grown from inoculated seeds with different seed-fungus contact periods ( $0 \mathrm{~h}, 36 \mathrm{~h}, 72 \mathrm{~h}, 108 \mathrm{~h}$, and $144 \mathrm{~h}$ ), corresponding to the inoculum potentials $\mathrm{P} 0, \mathrm{P} 36, \mathrm{P} 72, \mathrm{P} 108$, and $\mathrm{P} 144$, and grown at two temperatures $\left(20\right.$ and $\left.26^{\circ} \mathrm{C}\right)$. 


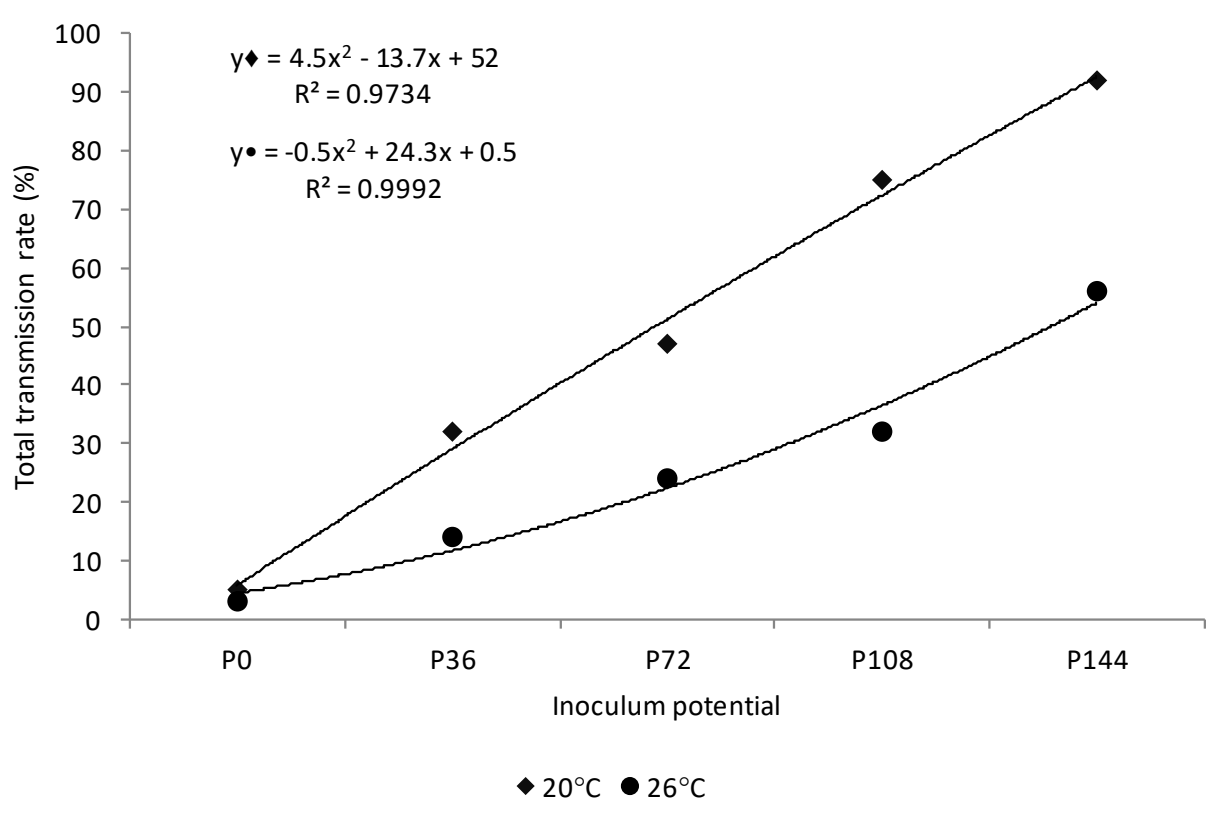

Figure 4. Total transmission rate of Colletotrichum lindemuthianum (race 65) from common bean seeds ('Pérola'), inoculated with different seed-fungus contact times $(0 \mathrm{~h}, 36 \mathrm{~h}, 72 \mathrm{~h}, 108 \mathrm{~h}$, and $144 \mathrm{~h})$, corresponding to the inoculum potentials $P 0, P 36, P 72, P 108$, and $P 144$ to plants grown at two temperatures $\left(20\right.$ and $\left.26^{\circ} \mathrm{C}\right)$, considering the evaluations of deaths in pre-emergence and transmissions rates in symptomatic and asymptomatic plants.

\section{CONCLUSIONS}

The transmission rate of $C$. lindemuthianum from infected common bean seeds is variable and directly proportional to the pathogen inoculum potentials in the seeds under favorable temperature condition for the disease development.

Higher percentages of total transmission rates of the fungus are observed at higher inoculum potentials and in growing seedlings at the temperature of $20^{\circ} \mathrm{C}$.

Under both growing conditions, 20 and $26^{\circ} \mathrm{C}, \mathrm{C}$. lindemuthianum was detected in tissues from parts of asymptomatic plants, and the highest transmission rates were observed at the temperature of $20^{\circ} \mathrm{C}$.

The incidence of $C$. lindemuthianum in the infected seeds was more verified in the region of the root collar in asymptomatic plants at the temperature of $20^{\circ} \mathrm{C}$, and these values increased in proportion to the increase of the inoculum potentials.

\section{ACKNOWLEDGMENTS}

Our thanks to the Universidade Federal de Lavras, to the Universidade Pedagógica de Quelimane, to the Coordenação de Aperfeiçoamento de Pessoal de Nível Superior (CAPES) for financial support through scholarships, to the Conselho Nacional de Desenvolvimento Cientifico e Tecnológico (CNPq) for support in carrying out this study, and to the SEPROTEC for providing seeds for this study.

\section{REFERENCES}

AGARWAL, V.K; SINCLAIR, J. B. Principles of seed pathology. Boca Raton: CRC Press, 1987. 176p.

BOTELHO, L.S.; ZANCAN, W.L.A.; MACHADO, J.C.; BARROCAS, E.N. Performance of common bean seeds infected by the fungus Sclerotinia sclerotiorum. Journal of Seed Science, v.35, n.2, p.153-160, 2013. http://www.scielo.br/pdf/jss/v35n2/03.pdf 
BRASIL. Ministério da Agricultura, Pecuária e Abastecimento. Regras para Análise de Sementes. Ministério da Agricultura, Pecuária e Abastecimento. Secretaria de Defesa Agropecuária. Brasília: MAPA/ACS, 2009a. 395p. https://www.abrates.org.br/files/regras_ analise_de_sementes.pdf

BRASIL. Ministério da Agricultura, Pecuária e Abastecimento. Manual de Análise Sanitária de Sementes. Ministério da Agricultura, Pecuária e Abastecimento. Secretaria de Defesa Agropecuária. Brasília: MAPA/ACS, 2009b. 202p. https://www.abrates.org.br/files/ manual-de-analise-sanitaria-de-sementes.pdf

FERREIRA, D.F. Sisvar: a computer statistical analysis system. Ciência e Agrotecnologia, v.35, n.6, p.1039-1042, 2011. http://www. scielo.br/pdf/cagro/v35n6/a01v35n6.pdf

FERREIRA, T.F.; CARVALHO, M.V.; FERREIRA, V.F.; MAVAIEIE, D.P.R.; GUIMARÃES, G.C.; OLIVEIRA, J.A. Sanitary quality of soybean seeds treated with fungicides and insecticides before and after storage. Journal of Seed Science, v.41, n.3, p.293-300, 2019.

HALL, R. Compendium of Bean Diseases. Saint Paul: The American Phytopathological Society Press, 1991. 71p.

MACHADO, J.C.; BARROCAS, E.N.; COSTA, M.L.N.; GUIMARÃES, R.M; MACHADO, C. Uso da técnica de restrição hídrica ou condicionamento osmótico em patologia de sementes. Revisão Anual de Patologia de Plantas, v.20, p.37-63, 2012.

MARINGONI, A.C.; BARROS, E.M. Ocorrência de isolados de Colletotrichum lindemuthianum resistentes a fungicidas benzimidazóis. Summa Phytopathologica, v.28, n.2, p.197-200, 2002. https://www.researchgate.net/profile/Antonio_Maringoni/ publication/265231302_Occurrence_of_isolates_of_Colletotrichum_lindemuthianum_resistant_to_benzimidazole_fungicides/ links/5405d08e0cf2c48563b1b8b4/Occurrence-of-isolates-of-Colletotrichum-lindemuthianum-resistant-to-benzimidazole-fungicides.pdf

MICHEL, B.E.; RADCLIFFE, D.A. Computer program relating solute potential to solution composition for five solutes. Agronomy Journal, v.87, n.1, p.131-136, 1995. https://doi.org/10.2134/agronj1995.00021962008700010022x

NEEGARD, P. Seed Pathology. London: The MacMillan Press, 1979. 839p.

NOETZOLD, R.; ALVES, M.C.; CASSETARI-NETO, D.; MACHADO, A.Q. Variabilidade espacial de Colletotrichum truncatum em campo de soja sob três níveis de sanidade de sementes. Summa Phytopathologica, v.40, n.1, p.16-23, 2014. http://www.scielo.br/pdf/sp/ v40n1/v40n1a02.pdf

REY, M.S.; LIMA, N.B.; SANTOS, J.; PIEROBOM, D.R. Transmissão semente-plântula de Colletotrichum lindemuthinum em feijão (Phaseolus vulgaris). Arquivos do Instituto Biológico, v.76, n.3, p.465-470, 2009. http://www.biologico.agricultura.sp.gov.br/ uploads/docs/arq/v76_3/rey.pdf

SARTORI, A.F; REIS, E.M.; CASA, R.T. Quantificação da transmissão de Fusarium moniliforme de sementes para plântulas de milho. Fitopatologia Brasileira, v.29, n.4, p.456-458, 2004. https://www.researchgate.net/publication/26393418_Quantificacao_da_ transmissao_de_Fusarium_moniliforme_de_sementes_para_plantulas_de_milho

SIQUEIRA, C.S.; MACHADO, J.C.; BARROCAS, E.N.; ALMEIDA, M.F. Potential for transmission of Stenocarpella macrospora from inoculated seeds to maize plants grown under controlled conditions. Journal of Seed Science, v.36, n.2, p.154-161, 2014. http:// www.scielo.br/pdf/jss/v36n2/v36n2a03.pdf

SIQUEIRA, C.S.; BARROCAS, E.N.; MACHADO, J.C.; CORRÊA, C.L. Transmission of Stenocarpella maydis by maize seeds. Revista Ciência Agronômica, v.47, n.2, p.393-400, 2016. http://ccarevista.ufc.br/seer/index.php/ccarevista/article/view/2764/1374

TALAMINI, V.; POZZA, E.A.; MACHADO, J.C.; OLIVEIRA, F.A. Epidemiologia de doenças associadas a Colletotrichum spp. transmitidas por sementes. Revisão Anual de Patologia de Plantas, v.10, p.219-248, 2001.

VECHIATO, M.H.; CASTRO, J.L.; ISHIMURA, I.; SABINO, J.C.; MENTEN, J.O.M. Antracnose do feijoeiro: correlação entre severidade em vagens e a incidência do patógeno nas sementes. Fitopatologia Brasileira, v.22, n.2, p.159-163, 1997. http://biologico. agricultura.sp.gov.br/uploads/docs/arq/V68_1/15.pdf

VENTUROSO, L.R.; BACCHI, L.M.A.; GAVASSONI, W.L.; VENTUROSO, L.A.C.; PONTIM, B.C.A.; REIS, G.F. Inoculação de Sclerotinia sclerotiorum em sementes de oleaginosas: transmissão e seus efeitos sobre a emergência de plantas. Ciência Rural, v.45, n.5, p.788-793, 2015. http://www.scielo.br/pdf/cr/v45n5/0103-8478-cr-00-00-cr20140374.pdf

VIEIRA, C. Doenças e pragas do feijoeiro. Viçosa: UFV, 1988. 231p.

ZANCAN, W.L.A.; MACHADO, J.C.; BAUTE, N.L.; SOUSA, B.F.M. Relationship between mycelial inoculum of Sclerotinia sclerotiorum and performance of sunflower seeds under controlled conditions. Bioscience Journal, v.31, n.3, p.775-784, 2015. http://www.seer. ufu.br/index.php/biosciencejournal/article/view/26090/16463 